\title{
Temporal Trend Analysis and Probabilistic Rainfall Estimation for Bhopal District of Madhya Pradesh
}

\author{
Abhishek M. Waghaye*, R. D. Randhe, Mukesh Kumar and Y. A. Rajwade \\ Irrigation and Drainage Engineering Division, ICAR-Central Institute of Agricultural \\ Engineering, Bhopal, Madhya Pradesh, India \\ *Corresponding author
}

\begin{abstract}
A B S T R A C T
Keywords

Trend analysis, Mann Kendall, Sen's slope estimator, Probabilistic rainfall

Article Info

Accepted:

12 November 2020

Available Online:

10 December 2020

The rainfall analysis including temporal trend is essential for assessing the water scarcity situation of particular region. In this study, the trend analysis of rainfall was carried out using non parametric Mann Kendall and Sen's slope estimator test. The monthly rainfall of 31 years (1985-2015) of Bhopal district was analyzed for detection of trend and estimation of probabilistic rainfall. The probabilistic rainfall was estimated using frequency factor method at 20\%, 50\% and $80 \%$ probability level. Analysis of 31 years rainfall data showed an average annual rainfall of $1044.7 \mathrm{~mm}$. The $25 \%$ deficit criteria for drought indicate that year 1992, 2000 and 2002 were dry years. The results showed the presence of statistically non significant decreasing trend in annual and seasonal (pre-monsoon, post-monsoon and monsoon) rainfall series. The annual probabilistic rainfall was found to be $1573.1 \mathrm{~mm}$, $916.5 \mathrm{~mm}$ and $411.5 \mathrm{~mm}$ at $20 \%, 50 \%$ and $80 \%$ probability level, respectively. The results have an important significance in planning and management of water resources and decision making process.
\end{abstract}

\section{Introduction}

Climate change generally refers to statistically significant change in mean climatic or meteorological parameters viz. rainfall, temperature, solar radiation, etc. over the time caused by naturally or anthropogenic sources. Climate change will result in significant impact on agriculture in terms of change in crop yield, crop duration and sequence and irrigation water requirement (Challinor et al., 2014; Rajwade et al., 2015). Rainfall is the most important weather variable for production of agricultural commodity. The magnitude and distribution of rainfall during crop period has effect on rainfed crops. Specifically over India, lower number of monsoon depressions and the increase in the number of dry spells resulted in overall decrease in seasonal mean rainfall. Therefore, rainfall analysis and its temporal trend determination can derive useful information for water resource management of the region.

The several researchers worked on the variability analysis of rainfall in several parts of world. Various parametric and nonparametric tests are used for trend analysis of 
hydro-meteorological time series variables such as rainfall (Kisi and Ay, 2014). The nonparametric Mann-Kendall test and Sen's slope estimator was utilized in different research studies for trend detection in rainfall time series. The significant and positive trends in rainfall have been observed in the USA (Kunkel et al., 1999), South Africa (Mason et al., 1999) and the United Kingdom (Osborn et al., 2000). In India, Pandey et al., (2017) found both positive and negative trends in rainfall over different regions of India by Mann-Kendall test and discrete wavelet transformation. Waghaye et al., (2018) investigated the rainfall trend using Mann-Kendall test and Sen's slope estimator for districts of Andhra Pradesh and Telangana and found increasing trend in annual rainfall series.

The rainfall time series analysis is needed to estimate probabilistic rainfall at different return period due to the uneven and erratic nature of rainfall. The estimated rainfall may have important role in design of various water harvesting, irrigation and hydraulic structures.

The probabilistic rainfall estimation can be done based on best fit probability distribution. While estimating the probabilistic rainfall, $50 \%$ and $80 \%$ probability should be considered as $80 \%$ probability indicates assured rainfall, while 50 per cent is maximum limit for taking any risk (Bhakar et al., 2006).

In India, the contribution (production) of rainfed agriculture is about $44 \%$ of the total food grain, supporting $40 \%$ population from $67 \%$ of sown area. Among the total cultivated area (14.9 Mha) in Madhya Pradesh, 62\% is rainfed, where climate is vital factor. Long term weather analysis is important for deciding future directions and/or alterations required in existing system for sustainable crop production. Hence, it is imperative to analyze rainfall data for trend analysis to determine the rainfall pattern of the region In addition, the probabilistic rainfall estimation provides information on expected rainfall for better planning and management of water resources. In view of above, the aim of present study is to determine the trend in rainfall series along with probabilistic rainfall estimation for Bhopal district of Madhya Pradesh.

\section{Materials and Methods}

\section{Study area}

Bhopal district of Madhya Pradesh state, situated between the latitudes $23^{\circ} 05^{\prime}$ $23^{\circ} 54^{\prime} \mathrm{N}$ and longitudes $77^{\circ} 10^{\prime}-77^{\circ} 40^{\prime} \mathrm{E}$ with an average altitude of $500 \mathrm{~m}$ above mean sea level. The climate of Bhopal district is a humid sub-tropical with cool and dry winters and hot summers falling in the agro-climatic zone of 'Vindhya Plateau'. May is hottest month with maximum mean temperature of $40.7^{\circ} \mathrm{C}$ and mean minimum temperature of $11.3^{\circ} \mathrm{Cwas}$ observed during January. The mean relative humidity varies between the minimum of $26 \%$ during the summer months and maximum of $88 \%$ during the monsoon season (MoWR, 2013). The location of study area is shown in Fig. 1.

\section{Data collection and analysis}

The daily rainfall data of31 years (1985-2015) for Bhopal district was collected from the meteorological observatory of ICAR-Central Institute of Agricultural Engineering, Bhopal. The rainfall parameters mean, standard deviation, coefficient of variation, skewness and kurtosis were determined.

\section{Trend analysis}

The non-parametric tests Mann Kendall test (MK) and Sen's slope estimator were applied 
to 31 years rainfall series to determine rainfall trend and its magnitude.

\section{Mann Kendall test}

The Mann-Kendall test (Mann, 1945; Kendall, 1975) is most commonly used non parametric test for detection of trend in time series data of hydrologic variables. The test statistic is given by equation (2);

$S=\sum_{k=1}^{n-1} \sum_{j=k+1}^{n} \operatorname{sgn}\left(X_{j}-X_{k}\right)$

Where $X_{1}, X_{2}, X_{3}, \ldots, X_{n}$ represents data points and $X_{j}$ represents at $j^{\text {th }}$ time. Positive test statistic indicates the increasing trend and vice versa.

So,

$\operatorname{sgn}(x)=\left\{\begin{array}{l}1 \text { if } x \geq 0 \\ 0 \text { if } x=0 \\ -1 \text { if } x<0\end{array}\right.$

The $\mathrm{E}[\mathrm{S}]=0$ and variance is given by,

variance $V[S]=\frac{n(n-1)(2 n+5)-\sum_{i=1}^{m} t_{i}\left(t_{i}-1\right)\left(2 t_{i}+5\right)}{18}$

Where $n$ is number of data points, $m$ is the number of tied groups in data set and $t_{j}$ is number of data points in $\mathrm{j}^{\text {th }}$ tied group. The standardized z-statistic is given by equation (3);

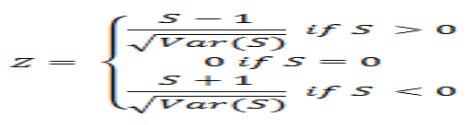

\section{Sen's slope estimator test}

This test is used estimate rate of change (slope) of variable over the period (Sen, 1968). The value of $d_{k}$ is given by equation (4);

$d_{k}=\frac{X_{j}-X_{i}}{j-i}$
For all $1 \leq \mathrm{i} \leq \mathrm{j} \leq \mathrm{n}$

Sens slope is given by median of all slopes. $b$ $=$ median $\left(d_{k}\right)$. The intercepts at each time ' $\mathrm{t}$ ' are computed by,

$a_{t}=X_{t}-b \times t$

\section{Probabilistic rainfall estimation}

The monthly rainfall series of 31 years (19852015) for monsoon season (June-September) was analyzed to estimate probabilistic rainfall at different probability level $(20 \%, 50 \%$ and $80 \%$ ). The probability distributions such as lognormal, gumbel max, weibull, gamma, generalized extreme value were fitted to monthly rainfall series. The goodness of fit was tested using Chi-square test (eq.1) and based on test statistic value, the rankings were applied to the different probability distributions. Based on best fit distribution, a frequency factor method (eq. 1) was applied for rainfall estimation at different probability level (Waghaye et al., 2015).

$X_{T}=\bar{X}+K_{T} \sigma$

Where, $\mathrm{X}_{\mathrm{T}}$ is the variate value of $\mathrm{X}$ of return period $\mathrm{T}$,

$\bar{X}_{\text {is the Mean, }}$

$\mathrm{K}_{\mathrm{T}}$ is the frequency factor,

$\sigma$ is the Standard deviation

\section{Results and Discussion}

\section{Rainfall analysis}

The statistical parameters have been calculated on monthly and annual basis as shown in Table 2. On the basis of 31 years annual rainfall series, mean annual rainfall was found to be $1044.7 \mathrm{~mm}$. The maximum and minimum rainfall of $1931.5 \mathrm{~mm}$ and $579.4 \mathrm{~mm}$ was observed during2006 and 
2000, respectively (Fig. 2). Based on meteorological drought year criteria, years 1992, 2000 and 2002 were found to be dry years. Monsoon (Jun-Sept), post monsoon (Oct.-Feb.) and pre monsoon (Mar-May) seasonal analysis showed that maximum $88.7 \%$ of the annual rainfall was received during the monsoon season. In post monsoon and pre monsoon season, only $6.9 \%$ and $4 \%$ of total annual rainfall was observed, respectively.
The standard deviation varied from 9 to 175.3 $\mathrm{mm}$ over the different month. The skewness varied from -0.3 and 4.5 which indicates the asymmetric nature of monthly rainfall during the period. The peakedness of a symmetrical frequency distribution was explained by the kurtosis (Goyal, 2014), which varied from 0 to 22.7. The coefficient of variation gives the inter-annual variability of annual rainfall in each of the stations and found to be varied from 0.4 to 3.4 over different months.

Table.1 Statistical parameters of rainfall series of Bhopal

\begin{tabular}{|l|l|l|l|l|l|l|l|}
\hline Month/ Annual & Mean & SD & CV & Minimum & Maximum & Skewness & Kurtosis \\
\hline January & 12 & 20.8 & 1.7 & 0 & 64.7 & 1.7 & 1.4 \\
\hline February & 10.3 & 14.9 & 1.4 & 0 & 54.8 & 1.4 & 1.4 \\
\hline March & 13.6 & 26.2 & 1.9 & 0 & 116.9 & 2.6 & 7.7 \\
\hline April & 6.1 & 9 & 1.5 & 0 & 40.7 & 2.2 & 5.8 \\
\hline May & 15.4 & 21.8 & 1.4 & 0 & 79.9 & 1.7 & 2.3 \\
\hline June & 134.8 & 100.2 & 0.7 & 14.6 & 453 & 1.4 & 2.4 \\
\hline July & 314.3 & 125.4 & 0.4 & 19.2 & 535.7 & -0.3 & 0.3 \\
\hline August & 321.1 & 175.3 & 0.5 & 131.3 & 937.2 & 1.6 & 3.6 \\
\hline September & 156.2 & 117.7 & 0.8 & 1.8 & 450.2 & 0.8 & 0 \\
\hline October & 30.3 & 39.3 & 1.3 & 0 & 149.3 & 1.6 & 2.1 \\
\hline November & 11.2 & 37.9 & 3.4 & 0 & 197.5 & 4.5 & 21.1 \\
\hline December & 8.1 & 23.7 & 2.9 & 0 & 127.2 & 4.5 & 22.7 \\
\hline Annual & 1044.7 & 283 & 27.1 & 579.4 & 1931.5 & 0.9 & 1.8 \\
\hline
\end{tabular}

Table.2 Homogeneity analysis of rainfall

\begin{tabular}{|c|c|c|c|}
\hline $\begin{array}{c}\text { Station \&Data } \\
\text { Bhopal, 31 years } \\
(\mathbf{1 9 8 5 - 2 0 1 5})\end{array}$ & $\begin{array}{c}\text { SNHT } \\
(\mathrm{p} \text { value }=0.96)\end{array}$ & $\begin{array}{c}\text { Buishand's test } \\
\text { Homogenous } \\
(\mathrm{p} \text { value }=0.95)\end{array}$ & $\begin{array}{c}\text { von Neumann's test } \\
(\mathrm{p} \text { value }=0.89)\end{array}$ \\
\hline
\end{tabular}

Table.3 Mann Kendall test statistic (Z), Sen Slope estimator ( $\beta$ ) test and percentage change for annual and seasonal rainfall

\begin{tabular}{|c|c|c|c|c|c|c|c|c|c|c|c|c|}
\hline Station & $\mathbf{Z}$ & $\boldsymbol{\beta}$ & $\begin{array}{l}\% \\
\text { change }\end{array}$ & $\mathbf{Z}$ & $\boldsymbol{\beta}$ & $\begin{array}{l}\% \\
\text { change }\end{array}$ & $\mathbf{Z}$ & $\beta$ & $\begin{array}{l}\% \\
\text { change }\end{array}$ & $\mathbf{Z}$ & $\beta$ & $\begin{array}{l}\% \\
\text { change }\end{array}$ \\
\hline & \multicolumn{3}{|c|}{ Annual } & \multicolumn{3}{|c|}{ Monsoon } & \multicolumn{3}{|c|}{ Post-monsoon } & \multicolumn{3}{|c|}{ Pre-monsoon } \\
\hline Bhopal & -0.61 & -2.7 & \begin{tabular}{l|l}
7 & -7.98
\end{tabular} & -0.85 & -0.9 & -12.5 & -0.87 & -0.13 & -25.2 & -0.1 & -0.04 & -7.8 \\
\hline
\end{tabular}


Table.4 Monthly estimated rainfall for monsoon season

\begin{tabular}{|c|c|c|c|c|c|}
\hline Month & $\begin{array}{c}\text { Average } \\
\text { rainfall (mm) }\end{array}$ & $\begin{array}{c}\text { Standard } \\
\text { deviation }(\mathbf{m m})\end{array}$ & $\begin{array}{c}\text { Probability } \\
(\%)\end{array}$ & $\begin{array}{l}\text { Frequency } \\
\text { factor }\end{array}$ & $\begin{array}{c}\text { Estimated } \\
\text { rainfall }(\mathbf{m m})\end{array}$ \\
\hline \multirow[t]{3}{*}{ June } & \multirow[t]{3}{*}{134.8} & \multirow[t]{3}{*}{100.2} & 20 & 0.758 & 210.73 \\
\hline & & & 50 & -0.164 & 118.4 \\
\hline & & & 80 & -0.993 & 35.32 \\
\hline \multirow[t]{3}{*}{ July } & \multirow{3}{*}{314.3} & \multirow{3}{*}{125.4} & 20 & 0.758 & 409.3 \\
\hline & & & 50 & -0.164 & 293.7 \\
\hline & & & 80 & -0.993 & 189.8 \\
\hline \multirow[t]{3}{*}{ August } & \multirow[t]{3}{*}{321.1} & \multirow[t]{3}{*}{175.3} & 20 & 0.758 & 454 \\
\hline & & & 50 & -0.164 & 292.4 \\
\hline & & & 80 & -0.993 & 147 \\
\hline \multirow[t]{3}{*}{ September } & \multirow[t]{3}{*}{156.2} & \multirow[t]{3}{*}{117.7} & 20 & 0.758 & 245.4 \\
\hline & & & 50 & -0.164 & 136.9 \\
\hline & & & 80 & -0.993 & 39.4 \\
\hline
\end{tabular}

Fig.1 Location of study area



Fig.2 Total annual rainfall recorded for the period 1985-2015

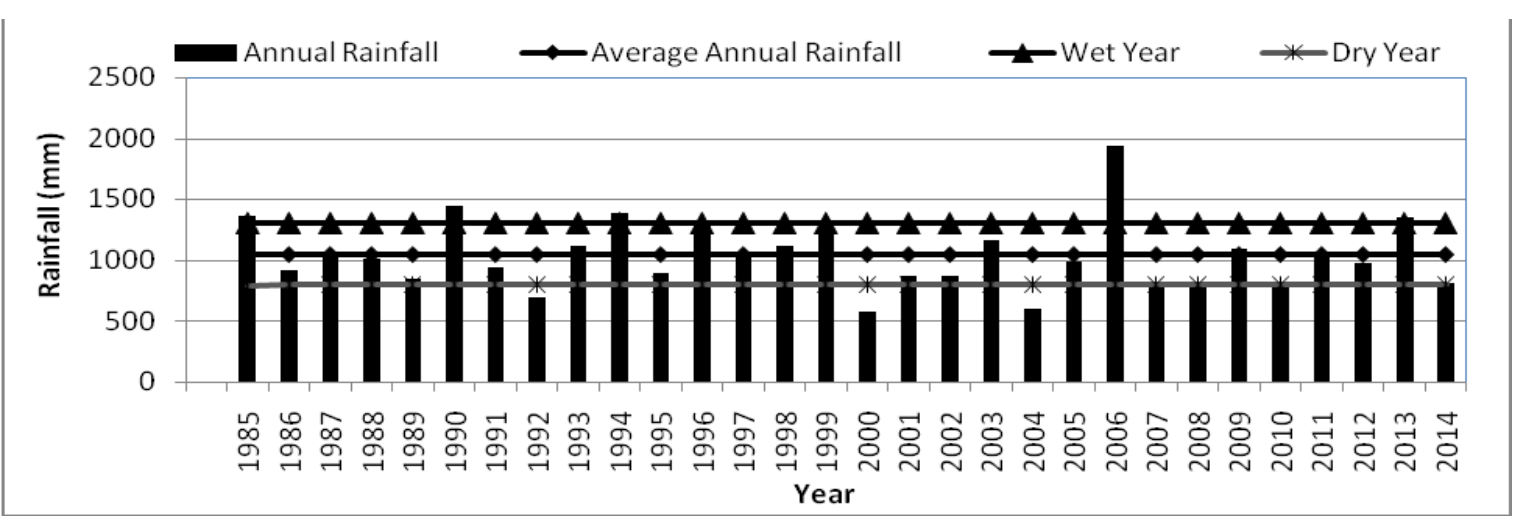


Fig.3 Estimated seasonal rainfall at 20, 50 and 80\% probability level

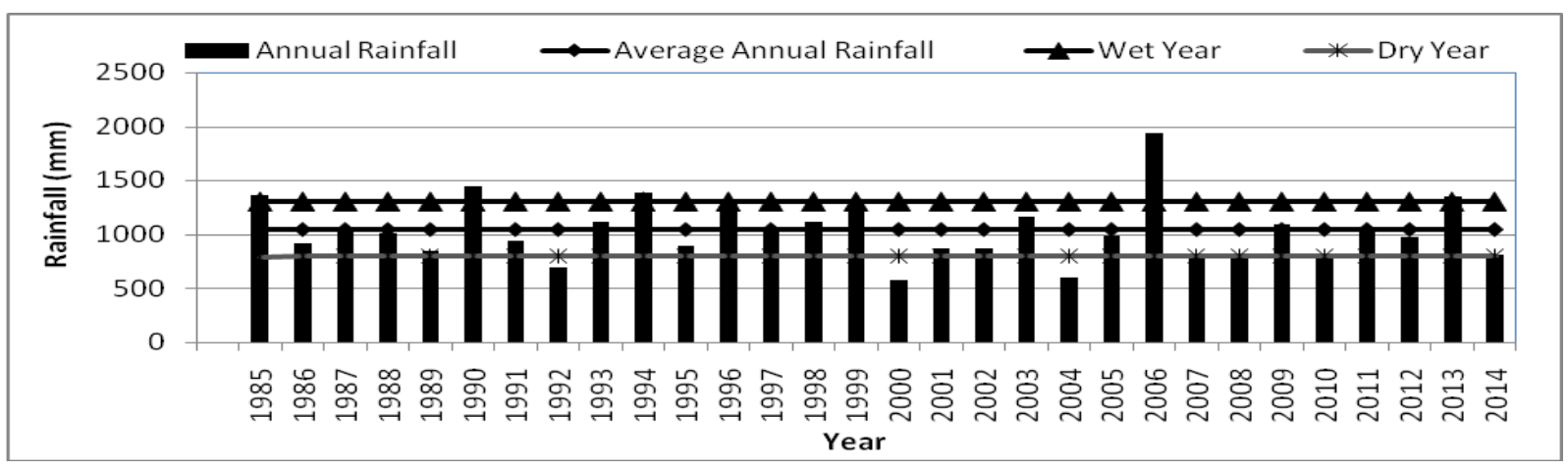

\section{Homogeneity test}

The three different tests (SNHT test, Buishand's test and von Neumann's test) were applied to the rainfall series of Bhopal to check the homogeneity of rainfall series at 5\% significance level. The results of the homogeneity tests revealed that the rainfall series was homogenous for Bhopal stations (Table 3).

\section{Trend analysis}

The rainfall trend has been determined using non-parametric MK test and Sen's slope estimator test for annual and seasonal (premonsoon, monsoon and post-monsoon) rainfall series. The MK test showed statistically nonsignificant decreasing trend in rainfall series (Table 4). The magnitude of the trends in annual rainfall was $-2.7 \mathrm{~mm}$ per year. The decrease of $7.98 \%$ in percentage change in annual rainfall was observed at Bhopal station. The MK test applied to the seasonal rainfall series showed decreasing trend with magnitude of the trends, $-0.04,-0.9$ and $0.13 \mathrm{~mm} /$ year for pre-monsoon, monsoon and post-monsoon season respectively. The percentage decrease of $7.8 \%, 12.5 \%$ and $25.2 \%$ was observed in pre-monsoon, monsoon and post-monsoon season, respectively.

\section{Design rainfall estimation}

On the basis of Chi-Square test, Gamma distribution was best fitted to monthly rainfall series. Using frequency factor method, rainfall was estimated at $20 \%, 50 \%$ and $80 \%$ probability level (Table 5).For monsoon season, the seasonal estimated rainfall at $20 \%$, $50 \%$ and $80 \%$ probability level was found to be $1319.4,841.4$, and $411.5 \mathrm{~mm}$ respectively (Fig. 3). The annual design rainfall was found to be $1573.1 \mathrm{~mm}, 916.5 \mathrm{~mm}$ and $411.5 \mathrm{~mm}$ at $20 \%, 50 \%$ and $80 \%$ probability level respectively.

In conclusion the rainfall is important for rainfed dependent small holder farmers The rainfall variability analysis has significant role for planning and management of agricultural activities to overcome challenge of poverty in developing nations. The analysis of 31 years rainfall data using MK test and Sen's slope estimator test revealed the presence nonsignificant decreasing trend in annual rainfall series. The monsoon rainfall series showed a presence of non-significant decreasing trend in rainfall series. The estimated seasonal rainfall in monsoon season at 20\%, 50\%, 80\% probability level was found to be $1319.4 \mathrm{~mm}$, $841.4 \mathrm{~mm}$ and $411.5 \mathrm{~mm}$ respectively. Results help in analyzing the changing climate, its effect on water resources and to take better agricultural decisions. 


\section{References}

Bhakar, S.R., Bansal, A.N., Chhajed, N.,and Purohit, R.C., 2006. Frequency analysis of consecutive days maximum rainfall at Banswara, Rajasthan, India. ARPN Journal of Engineering and Applied Sciences, 1(3): 64-67.

Challinor, A.J., Watson, J., Lobell, D.B., Howden, S.M., Smith, D.R; Chhetri N. 2014. A meta-analysis of crop yield under climate change and adaptation. Nature Climate Change 4(4): 287.

Goyal M K. 2014. Statistical analysis of long term trends of rainfall during 1901-2002 at Assam, India. Water Resource Management 28: 1501-1515.

Kendall M G. 1975. Rank Correlation Methods, second ed. (New York:Hafner)

Kisi O; Ay M. 2014. Comparison of MannKendall and innovative trend method for water quality parameters of the Kizilirmak River, Turkey. Journal of Hydrology, 513: 362-375.

Kunkel K E; PielkerJr R A; Changnon S A. 1999. Temporal fluctuation in winter and climate extremes that cause economic and human health impact: a review. International Journal of Climatology19: 1077-1098.

Mann H B. 1945. Nonparametric tests against trend. Econometrica, 13: 245-259.

Mason S J; Waylen P R; Mimmack G M; Rajaratnam B; Harrison J M. 1999. Changes in extreme rainfall events in South Africa. Climatic change, 41(2): 249-257.

MoWR 2013. District Ground Water
Information Booklet, Bhopal District, Madhya Pradesh, Ministry of Water Resources, Central Ground Water Board, North Central Region, Bhopal. (Site:http://cgwb.gov.in/District_Profile/ MP/Bhopal.pdf; Accessed Oct. 2018)

Osborn T J; Hulme M; Jones P D; Basnett T A. 2000. Observed trends in the daily intensity of United Kingdom precipitation. International Journal of Climatology20: 347-364.

Pandey B K; Tiwari H; Khare D. 2017. Trend analysis using discrete wavelet transform (DWT) for long-term precipitation (1851-2006) over India. Hydrological Sciences Journal 62(13): 2187-2208.

Rajwade Y A; Swain D K; Tiwari K N; Mohanty U C; Goswami P. 2015. Evaluation of field level adaptation measures under the climate change scenarios in rice based cropping system in India. Environmental Processes, 2(4): 669-687.

Sen P K. 1968. Estimates of the regression coefficient based on Kendall's tau. Journal of American Statistical Association, 63: 1379-1389.

Waghaye A M; Rajwade Y A; Randhe R D; Kumari N. 2018. Trend analysis and change point detection of rainfall of Andhra Pradesh and Telangana, India. Journal of Agrometeorology 20(2): 160163.

Waghaye A M; Siddenki V; Nidhi K. 2015. Design rainfall estimation using probabilistic approach for Adilabad district of Telangana. International Journal of Advanced Scientific Research 2(5): 301-18.

\section{How to cite this article:}

Abhishek M. Waghaye, R. D. Randhe, Mukesh Kumar and Rajwade, Y. A. 2020. Temporal Trend Analysis and Probabilistic Rainfall Estimation for Bhopal District of Madhya Pradesh. Int.J.Curr.Microbiol.App.Sci. 9(12): 1364-1370. doi: https://doi.org/10.20546/ijcmas.2020.912.166 